\title{
Neurobiology of Vascular Dementia
}

\author{
Ana-Maria Enciu, ${ }^{1}$ Stefan N. Constantinescu, ${ }^{1,2}$ Laurenţiu M. Popescu, ${ }^{1,3}$ \\ Dafin F. Mureşanu, ${ }^{4}$ and Bogdan O. Popescu ${ }^{3,5,6}$ \\ ${ }^{1}$ Department of Cellular and Molecular Medicine, School of Medicine, "Carol Davila" University of Medicine and Pharmacy, \\ 8 Eroilor Sanitari, Sector 5, 050474 Bucharest, Romania \\ ${ }^{2}$ Ludwig Institute for Cancer Research Ltd., de Duve Institute, Université Catholique de Louvain, 1200 Bruxelles, Belgium \\ ${ }^{3}$ Laboratory of Molecular Medicine, "Victor Babeş" National Institute of Pathology, 99-101 Splaiul Independenţei, Sector 5, \\ 050096 Bucharest, Romania \\ ${ }^{4}$ Department of Neurology, "Iuliu Hatieganu" University of Medicine and Pharmacy, 8 Victor Babeş, 400023 Cluj-Napoca, Romania \\ ${ }^{5}$ Department of Neurology, University Hospital Bucharest, "Carol Davila” University of Medicine and Pharmacy, \\ 169 Splaiul Independenței, Sector 5, 050098 Bucharest, Romania \\ ${ }^{6}$ International Clinical Research Center, St. Anne’s University Hospital Brno, 53 Pekařská, 65691 Brno, Czech Republic
}

Correspondence should be addressed to Bogdan O. Popescu, bogdan.popescu@jcmm.org

Received 14 June 2011; Revised 27 June 2011; Accepted 28 June 2011

Academic Editor: Aurel Popa-Wagner

Copyright (C) 2011 Ana-Maria Enciu et al. This is an open access article distributed under the Creative Commons Attribution License, which permits unrestricted use, distribution, and reproduction in any medium, provided the original work is properly cited.

Vascular dementia is, in its current conceptual form, a distinct type of dementia with a spectrum of specific clinical and pathophysiological features. However, in a very large majority of cases, these alterations occur in an already aged brain, characterized by a milieu of cellular and molecular events common for different neurodegenerative diseases. The cell signaling defects and molecular dyshomeostasis might lead to neuronal malfunction prior to the death of neurons and the alteration of neuronal networks. In the present paper, we explore some of the molecular mechanisms underlying brain malfunction triggered by cerebrovascular disease and risk factors. We suggest that, in the age of genetic investigation and molecular diagnosis, the concept of vascular dementia needs a new approach.

\section{Vascular Dementia-Historical Considerations}

Just how far back in time should one go when searching data of vascular dementia (VaD)? In 1549, Jason Pratensis published De Cerebri Morbi, linking dementia to stroke [1], and in 1658, Johann Jakof Wepfer theorized that a broken brain blood vessel may cause apoplexy (stroke) [2]. The correlation between atherosclerotic disease and dementia was clearly identified only at the beginning of the 20th century by two well-known contributors to the field of neurodegeneration: Alois Alzheimer and Otto Binswanger [3]. The modern era of vascular dementia began in the 1960s, under the leadership of the Newcastle College of Medicine [4]. The concept of $\mathrm{VaD}$ was ever since under permanent scrutiny and revision, in light of new clinical, pathological, and imagery data (Figure 1). In the early 1970's, multiple infarct dementia was recognized as a major type of dementia, apart from Alzheimer's disease, characterized not by "neuronal atrophy" but by atherosclerotic burden. In 1975, Vladimir Hachinski defined the "ischemic score," later used for the clinical diagnostic of vascular dementias [5]. However, the concept of $\mathrm{VaD}$ soon became controversial due to an increased discrepancy between the incidence of cognitive disorders and that of the "strategic stroke." Furthermore, the early prevention of multi-infarct dementia (MID), the aging of the general population, and an arising need to define "normal aging" versus "pathological aging" [6] added to this controversy. The struggle to identify preventable and treatable factors widened the pathogenic spectrum of $\mathrm{VaD}$ [7]. Several epidemiological studies reported associations of hypertension, type 2 diabetes, obesity, and inflammation with VAD and, in some cases, AD. These all coincide with those of stroke, which in turn is an established factor for 
cognitive decline and VAD [8] and underlines furthermore the need for a new classification of dementia types [9]. During the last two decades, there was a switch of exploration from classical pathology to new imaging techniques at the molecular level. Therefore, new pathogenic pathways were identified, which greatly increased the complexity of mechanisms of neuronal loss due to cerebral vascular injury [10].

In each stage of clinical and imaging research, new attempts were made to define $\mathrm{VaD}$ as an individual, selfstanding class of dementia. Mayer-Gross et al. presented in the late $60 \mathrm{~s}$ a set a criteria including dementia with focal signs and symptoms consistent with stroke, a fluctuating course, preservation of intellectual powers, and personality until late in the disease. Importantly, definition included vascular risk factors such as hypertension [11].

The "multi-infarct dementia" (MID), first described by Vladimir Hachinski, was characterized by a number of small ischemic strokes that may not result in focal neurologic deficits, but in time, by cumulative damage, would lead to cognitive decline. Later, the Hachinski ischemic scale, used for MID diagnosis, was modified by Loeb and Gandolfo to include CT scan criteria [12].

In the 1990s, as acknowledgment of overlapping features of various types of dementia, VaD criteria included clinical and imaging features of probable and possible disease. Criteria for definite $\mathrm{VaD}$ would require histopathological evidence from biopsy or autopsy [13].

Currently, the most widely used criteria for VaD include the Diagnostic and Statistical Manual of Mental Disorders (DSM), Alzheimer's Disease Diagnostic and Treatment Centers (ADDTC), International Statistical Classification of Diseases (ICD), and National Institute of Neurological Disorders and Stroke-Association Internationale pour la Recherche et l'Enseignement en Neurosciences (NINDS-AIREN) criteria [14].

\section{The Concept of Brain Ageing}

The concept of brain ageing stated at first that cell death might be responsible for the progressive deterioration of different physiological functions. Studies on aged animals [15] from over two decades ago reported neuronal loss with aging, with or without cortical thinning (depending on the type of method used for quantification), but with diminution of the total volume of gray matter. By the end of the 1980s, reports of preserved neuronal number, despite cortical thinning in human brain [16], started to challenge the previous data and were followed by confirmatory studies on animals [17-20]. This controversy was solved by modern imaging investigational methods, starting with computer tomographic analysis in the early 1980's [21] and continuing with recent PET and MRI analyses [22, 23]. These techniques demonstrated that brain atrophy does occur with age in the healthy, nondemented elderly, involving both gray and white matter, but the loss is rather of neuronal connections, not of neurons. Furthermore, quantitation of neurons showed that, despite frontal and medial temporal cortical thinning, the number of neurons is preserved in healthy adults. Freeman et al. reported that, in frontal and temporal neocortical regions, the neuronal count remained relatively constant over a 50-year age range, suggesting that the atrophy is a reflection of the $3 \mathrm{D}$ neuronal network loosening rather than perikaryal loss [24]. The prefrontal cortical neurons seem to be particularly vulnerable to ageing, as a decrease in dendritic branching has been reported in neocortex of both rat [25] and human brains [26-28]. By contrast, there is no significant change in dendritic length of hippocampal granule cells, nor a reduction in spine density in the dentate gyrus of aged humans [29] or rats [30].

White matter reduction is also a consistent finding in the aged human brain, possibly as an indicator of defective myelination (although oligodendrocyte number seems to increase). White matter loss is strongly correlated with vascular risk factors, particularly hypertension and stroke [31], two pathologies included in the broad spectrum of $\mathrm{VaD}$ risk factors. However, the involvement of white matter abnormalities and the presence of lacunae yielded contradictory results in terms of functional integrity and cognitive impairment [32].

At the molecular level, aging is a "decrease in homeostatic reserve" [33] which interferes with neuronal ability to limit and buffer the increase of reactive oxygen species (ROS) production, to sustain a protective response to cytotoxic stimuli or to limit vicious cycles such as inflammatory environments. DNA damage increases with age (some of which is ROS related), somatic mutation in human lymphocytes being nine times more frequent in aged human subjects than in neonates [34], and mitochondrial DNA being even more sensitive than nuclear DNA. Mitochondrial aging brings its share of vulnerability to stress in aged cells, with decreased ATP reserves [35] along with affected cellular calcium removal systems and low buffering capacity [36]. Moreover, one should take into account the fact that, in the brain, these processes affect, at different rates, different cell types that share a homeostatic balance. On the other hand, understanding aging of the nervous tissue, as compared to other tissues, could be a more challenging task due to a more complex regulation, signaling, and intercellular interactions.

\section{VaD from a Molecular Perspective}

The molecular perspective on $\mathrm{VaD}$ is rather limited; the general concept of this type of cognitive impairment has derived from clinical and imaging findings and is correlated, at the cellular level, with neuronal death and the sudden interruption of neuronal networks. The main pathological changes leading to different forms of vascular dementia take place in both large (atherosclerosis and thrombosis) and small (lipohyalinosis and fibrosis) cerebral vessels, secondary to common vascular risk factors, such as hypertension, diabetes mellitus, and dyslipidemia. The reduction in cerebral blood flow (CBF) starts early during vascular disease [37] and, therefore, a major vascular event can be preceded by a variable period of chronic hypoxia. As a result, the brain cellular microenvironment might change and adaptive 


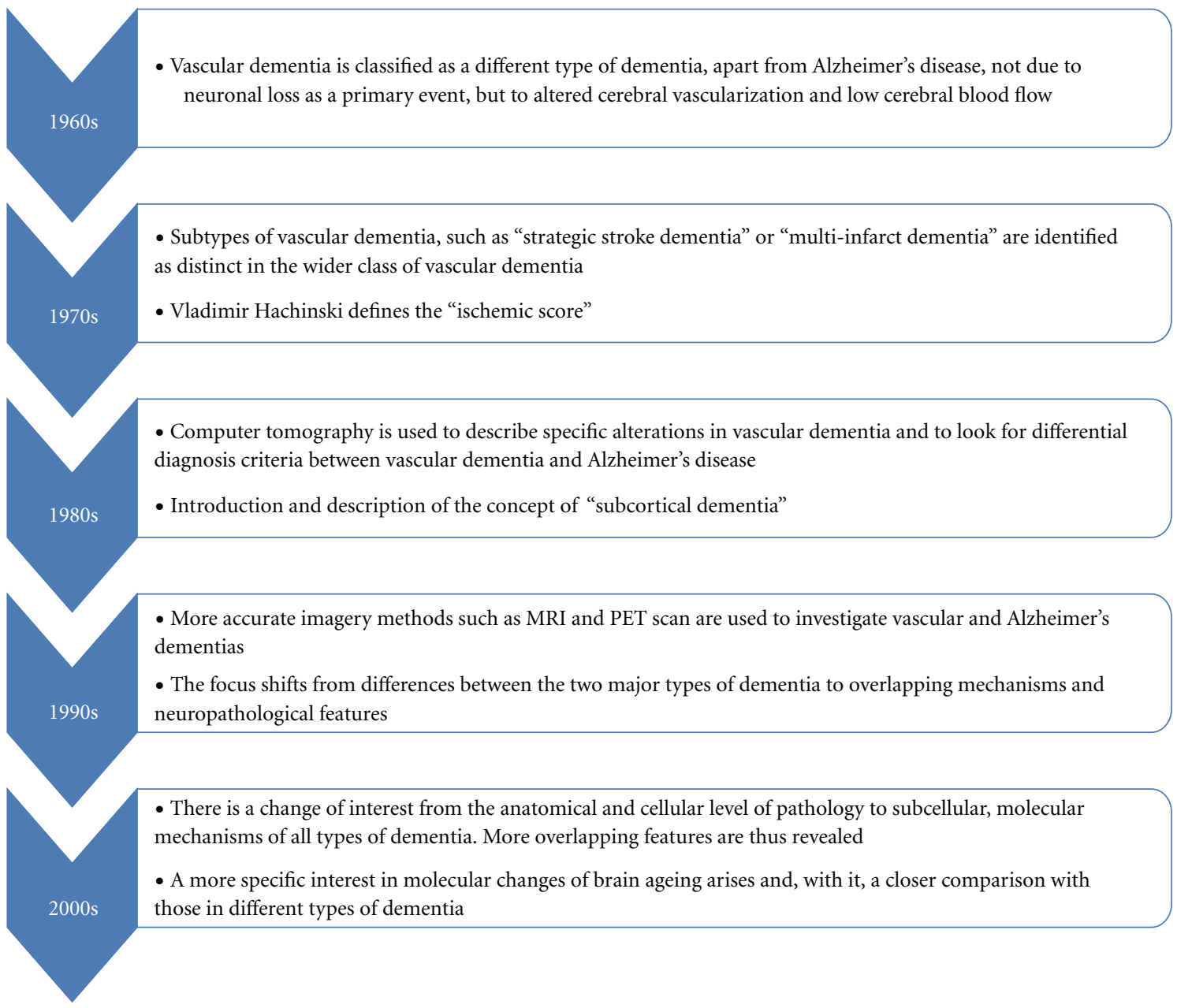

FIGURE 1: Evolution throughout time of vascular dementia concept.

processes may lead to cellular malfunction, rather than cellular death.

\subsection{Cerebral Blood Flow and Ischemia-Triggered Molecular} Events. Normal aging is associated with low cerebral flow and velocity at rest [38] and an attenuation of responsivity to hypoxia, hypercapnia, or blood pressure alterations [39]. These modifications may appear due to either histological alterations of the vessel wall (thickening of basement membrane, loss of pericytes, and an overall reduction in cortical vascular bed) or lower metabolic demand. The same changes in blood flow, but at a higher rate, were documented in subcortical ischemic VaD patients by PET studies, with some groups reporting a preferential decrease in frontal lobe regions [40]. In laboratory rats, chronic hypoxia increases the CBF for several days, after which a decrease towards the baseline is noted, probably due to compensatory mechanisms such as increased hematocrit and decreased metabolic needs [41]. Hypoxia inducible factor-1 (HIF-1) was used by Ritz et al. as a marker of hypoxia in the cortex of young (2 months) and old (9 months) spontaneously hypertensive rats (SHR) and stroke-prone SHR, in their study on hypoxic alterations of nonneuronal populations
[42]. Interestingly, the increase in HIF $1 \alpha$ was documented only in aged animals, along with an imbalance between microvessels and astrocytes at the level of the neurovascular unit. In hypoxic conditions, HIF- $1 \alpha$ is upregulated, dimerizes with HIF-1 $\beta$ (the constitutively expressed subunit of HIF-1), translocates into the nucleus, and binds to hypoxiaresponsive elements (HREs) of target genes, such as vascular endothelial growth factor (VEGF), glucose transporter1 (GLUT1), lactate dehydrogenase (LDH), erythropoietin (Epo), and nitric oxide synthase (NOS).

3.2. Inflammatory Cytokines, Adhesion Molecules, and Endothelial Malfunction. Endothelial malfunction is considered to be a first step in the development of atherosclerosis, and may be objectified by overexpression of inflammatory cytokines and adhesion molecules, leading to monocyte recruitment in the nascent atherosclerotic plaque and overproduction of reactive oxygen species (ROS), as a sign of mitochondrial, peroxisomal, and lysosomal alteration.

Measurements of plasma markers in $\mathrm{VaD}$ patients showed increased levels of proinflammatory cytokines (IL1, IL6, TNF $\alpha$ ) as well as anti-inflammatory cytokines (IL-10) 
[43]. IL-6 and TNF $\alpha$ levels increase with aging in animals and humans, and IL- 6 transgenic mice also show progressive proliferative cerebellar angiopathy and blood-barrier (BBB) breakdown. These events indicate the endothelium as one of the main targets of proinflammatory cytokine IL-6 [44]. The same transgenic strains indicated for the first time a causative relationship between local production of IL-6 in the brain and the age-related decline in learning and cognitive function, demonstrating dendritic vacuolization, stripping of dendritic spines, decreased synaptic density, and loss of GABA-producing neurons in the hippocampus. In association with neurodegenerative changes, a diffuse nonproliferative gliosis with marked activation of astrocytes and microglia was identified in GFAP-IL6 mice [45]. Furthermore, studies in transgenic mice overexpressing TNF and/or its receptors ( $\mathrm{p} 55$ and $\mathrm{p} 75^{\mathrm{NTR}}$ ) demonstrated that IL-6 is a potent microglial activator and, depending on the receptor it activates, (i) an endothelial activator (via p75 ${ }^{\mathrm{NTR}}$ ), leading to increased expression of adhesion molecules, BBB disruption, and CNS leukocyte infiltration or (ii) a demyelinating agent and oligodendrocyte apoptosis inducer via p55 [46]. According to Batti and O'Connor, although TNF $\alpha$ has no effect on synaptic transmission or long-term potentation (LTP) under basal conditions, it severely impairs the recovery of postsynaptic transmission after hypoxic exposure [47]. They also showed that the TNF $\alpha$ effect is p38/MAPK mediated, a signaling pathway involved as well in hypoxic neuronal death in the CA1 region of the hippocampus. But, in addition to its neurotoxic nature, $\mathrm{TNF} \alpha$ may also exert neuroprotective effects $[48,49]$ in selected signaling contexts.

Suggested to be another marker of chronic inflammation [50], E-selectin is an endothelial adhesion molecule, that is involved in weak linking of circulating leukocytes. Its expression is upregulated by IL-1 and TNF $\alpha$. Elevated levels of E-selectin have been previously linked to experimental and clinical brain ischemia [51], and high levels of soluble selectin (sE-selectin) have been correlated with severe cerebrovascular disease [50]. Generating immune tolerance against $\mathrm{E}$ selectin by repeated low-dose mucosal administration in lab rats had a protective effect against hemorrhagic strokes in HRS rats and against VCI development in Wistar rats, as shown by Wakita et al. [52].

3.3. Oxidative Stress. The impact of ROS on cognitive function is elegantly demonstrated by studies of superoxide dismutase (SOD) isoenzyme transgenic mice. Overexpression of mitochondrial SOD has a neuroprotective role against drug-induced neurotoxicity, overexpression of cytoplasmic SOD improves age-related impairments in LTP, and overexpression of extracellular SOD is correlated with better spatial memory in laboratory rats [53]. Following cerebral ischemia, the production of free radicals was increased in aged rats and human endothelial cells, mainly by overproduction in the monocyte/macrophage system, especially when stimulated by inflammatory mediators [54].

3.4. Effect of VaD Molecular Alterations on Neuronal and Glial Populations. Hypoxia is associated with increased expression of all NO synthase isoforms, including neuronal (nNOS), astrocyte and microglia-inducible isoform (iNOS), and endothelial isoform (eNOS) [55], which are involved in neuronal death through inhibition of mitochondrial respiration and $\mathrm{NMDA} / \mathrm{Ca}^{2+}$-induced exotoxicity $[56,57]$. Brain cells are particularly sensitive to ROS aggression due to their high content of polyunsaturated fatty acids, which constitute a substrate for lipid peroxidation. Exposure of brain cells to oxidative stress increases the accumulation of cholesterol in cell membranes [58], leading to decreased fluidity and impaired transmembrane transport.

Hypoxia also upregulates the expression of BDNF-a neurotrophic factor with important roles in neuroplasticity and hippocampus-related learning. This might serve as a protective mechanism against a paucity of hippocampal BDNF mRNA and BDNF plasma levels at older ages [59]. BDNF is further reduced by vascular risk factors such as hypertension and poor glucose metabolism [60]. However, hypoxic upregulation of BDNF is not accompanied by upregulation of its high-affinity receptor Trk-B, but of its low-affinity receptor $\mathrm{p} 75^{\mathrm{NTR}}$, a TNF superfamily receptor. The $\mathrm{p} 75^{\mathrm{NTR}}$ expression is upregulated by hypoxic conditions and is correlated with an increase in caspase- 3 activation in cortical and hippocampal neurons, leading to apoptosis [61]. The upregulation of $\mathrm{p} 75^{\mathrm{NTR}}$ is linked to NOS stimulation and to Ca-mediated regulation of expression, suggesting a complex transformation of the pattern of molecular expression in chronic ischemia and $\mathrm{VaD}$.

\section{Mixed versus Pure Dementia}

"Mixed" dementia is, by the very definition of Vladimir Hachinski himself, "Alzheimer's disease and cerebral infarcts contributing to the dementia" [6], but other coexisting pathologies are also common in dementia such as Parkinson disease (in about $20 \%$ of patients with $\mathrm{AD}$ ) and dementia with Lewy bodies (up to 50\%) [62].

Many data suggest that "pure" vascular dementia is rare and is the exception, rather than the rule [63-65]. Vasculopathy as a trigger of AD neuropathological features has been proposed repeatedly before [66-68], and it is very likely that a patient with late-onset $\mathrm{AD}$ may already have a vascular burden and shares with $\mathrm{VaD}$ vascular risk factors. Moreover, Zhang et al. demonstrated that the low-oxygen dependent increase in HIF $1 \alpha$ expression was accompanied by an increase of BACE1 protein levels and a secondary increase in $A \beta$ production [69]. These data suggest that restoration of normal oxygen levels to hypoxic tissues, for example, by the use of small molecules that lower the affinity of oxygen for hemoglobin, could be an interesting issue for research $[70,71]$.

Activation of inflammation is a consistent finding in $\mathrm{AD}$, as shown in cell culture models [72, 73], animal models [74, 75], and postmortem studies on AD brains [76-78].

Inflammation was related to the onset of cognitive decline and also correlated with disease progression by measurements of serum TNF $\alpha$ and the TNF $\alpha /$ IL1 $-\beta$ ratio. Patients with AD show elevated levels of TGF- $\beta$ that are 


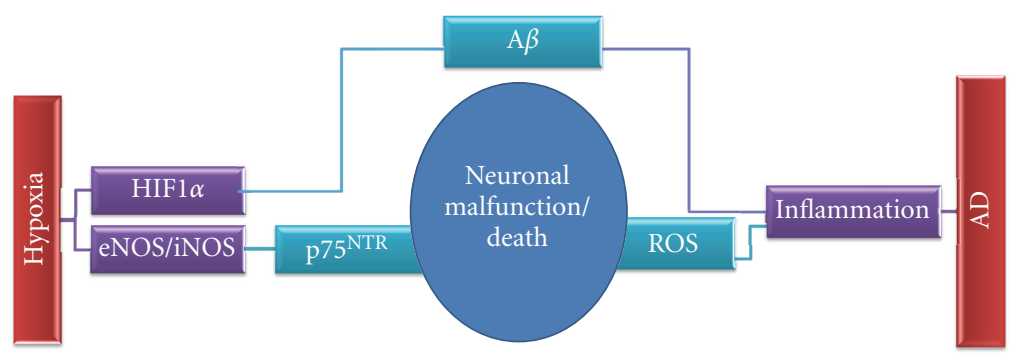

FIGURE 2: Some mechanisms converging towards neuronal malfunction in two major types of dementia.

correlated with low expression of TGF-R in the affected brain areas, especially around cerebral vessels with CAA [45]. Furthermore, inflammation is associated with ROS production, and oxidative stress has a dual relationship with $A \beta$ peptide: (i) it favors the aggregation of $A \beta$ into a fibrillar form and (ii) it mediates the toxic effect of $A \beta$ on neuronal cells, as shown by the protective effect of antioxidants and free radical scavengers [79]. In turn, some A $\beta$ peptides (such as the 25-35 form) have an intrinsic lipoperoxidizing effect, as established on neocortex-derived synaptosomes [80]. Oxidative stress is demonstrated by the increased amount of 4-hydroxynonenal (HNE), which was shown to interfere with plasmalemmal ATPases and transporters, including $\mathrm{Ca}^{2+}$ shifters, further increasing metabolic imbalance in AD.

Downstream $A \beta$ production and accumulation results in secondary endothelial malfunction through: (i) amyloid angiopathy; (ii) NOS inhibition [50]; (iii) atherogenesis correlated with endothelial activation and overexpression of inflammatory cytokines and adhesion molecules, even before $\mathrm{A} \beta$ deposition [81]; (iv) lipid peroxidation in the frontal cortex in AD brains [82]; (v) BBB alteration [83].

To conclude, there is an overlap of events between chronic hypoxia and $\mathrm{AD}$ on several levels, such as hypoxic-triggered cellular pathways, inflammatory environment, growth factor signalling, and calcium homeostasis (Figure 2). Thus, from the molecular level perspective, the diagnostic criteria for neurodegenerative diseases have become ill defined or insufficient and there is a true need for redefinition.

\section{Overlapping of Normal Aging and Neurodegenerative Diseases at Cellular and Molecular Level}

Normal aging and various types of neurodegeneration share common molecular events (Table 1), such as alteration of cerebral blood flow, neuroinflammatory environment, and endothelial malfunction.

Aging favors the production of proinflammatory cytokines, mostly through microglial and astrocytic activation [54]. Aging has also been associated, at the cellular level, with increased production of reactive oxygen species (ROS) [109]. Oxidative alteration of enzymes and the subsequent loss of enzymatic activity is a trait of the aging brain, particularly, in the anterior frontal lobe [49]. Oxidative stress leads to the accumulation of free cholesterol [79], along with ceramides, lipid peroxides, and derived aldehydes (such as HNE), that covalently bind to membrane proteins, altering their functions.

Oxidative stress is involved as well in the disruption of $\mathrm{Ca}^{2+}$ homeostasis, an effect studied especially in neurons, where $\mathrm{Ca}^{2+}$ is a vital mediator of neuronal signaling. It appears that, in aged neurons, several $\mathrm{Ca}^{2+}$ homeostatic systems are affected [33] and there is impairment in the maintenance of a nontoxic $\mathrm{Ca}^{2+}$ overload [120].

Although it seems that levels of nNOS and eNOS do not change with age, still there is an increase in NOS activity in aged rat cortex. These two NOS isoforms are $\mathrm{Ca}^{2+}$ induced, which correlates with the above-mentioned impairment of aged cells to deal with $\mathrm{Ca}^{2+}$ overload. Furthermore, consistent with the $\mathrm{Ca}^{2+}$-independent nature of iNOS, there are several reports underlining its absence in the normal aged cortex of lab rats $[15,60,105]$.

\section{Conclusions}

Instead of considering $\mathrm{VaD}$ a pure result of neuronal death and the interruption of neuronal networks that support cognitive function, we hypothesize that early brain malfunction is induced by vascular risk factors and chronic hypoxia. A reduction of $\mathrm{CBF}$ and a series of molecular events precede the major ischemic events in vascular cognitive impairment. Based on these subtle changes, intervention at early stages could prevent the full-blown development of dementia, which might represent a "point of no return" for the neurovascular units and neuronal networks with few chances for effective treatment.
Abbreviations
A $\beta$ : $\quad$ Amyloid beta peptide
p $75^{\mathrm{NTR}}$ : Low affinity receptor for tumor necrosis factor $\alpha$
HIF 1 $\alpha$ : Hypoxia Inducible Factor $1 \alpha$
ROS: Reactive oxygen species
eNOS: Endothelial nitric oxide synthase
iNOS: Inducible nitric oxide synthase. 
TABLE 1: Comparison between normal aging and neurodegenerative diseases from a molecular perspective.

\begin{tabular}{|c|c|c|c|c|}
\hline Parameter & Normal aging & Vascular dementia & Alzheimer's disease & $\begin{array}{l}\text { Other } \\
\text { neurodegenerative } \\
\text { disorders }\end{array}$ \\
\hline $\mathrm{CBF}$ & $\begin{array}{l}\text { Diminished with } \\
\text { lower velocity, but } \\
\text { with preserved } \\
\text { dynamic } \\
\text { adaptability [84] }\end{array}$ & $\begin{array}{l}\text { Diminished in parietal } \\
\text { and frontal lobes, some } \\
\text { authors reported also a } \\
\text { decrement in superior } \\
\text { temporal gyri, thalami, } \\
\text { anterior cingulate gyri } \\
\text { [85] }\end{array}$ & $\begin{array}{l}\text { Diminished only in } \\
\text { parietal cortices } \\
\text { and later in } \\
\text { advanced disease in } \\
\text { frontal lobes [86] }\end{array}$ & $\begin{array}{l}\text { Diminished in } \\
\text { preoccipital and } \\
\text { occipital regions in } \\
\text { PD [87] and LBD } \\
{[88]}\end{array}$ \\
\hline VEGF -A & $\begin{array}{l}\text { Low basal levels } \\
\text { produced by } \\
\text { astrocytes [89] }\end{array}$ & $\begin{array}{l}\text { Upregulation of VEGF } \\
\text { and VEGF R2 in } \\
\text { astrocytes [90] }\end{array}$ & $\begin{array}{l}\text { Low serum levels } \\
\text { and decreased } \\
\text { secretion by } \\
\text { peripheral immune } \\
\text { cells [91] }\end{array}$ & $\begin{array}{l}\text { FTLD_associated } \\
\text { with VEGF gene } \\
\text { promoter } \\
\text { polymorphism in } \\
\text { selected } \\
\text { populations [92] }\end{array}$ \\
\hline \multicolumn{5}{|l|}{$\begin{array}{l}\text { Inflammatory } \\
\text { cytokines }\end{array}$} \\
\hline IL-6 & $\begin{array}{l}\text { Increased mRNA } \\
\text { compared to young } \\
\text { subjects [93] }\end{array}$ & $\begin{array}{l}\text { High blood levels, } \\
\text { associated with high } \\
\text { CRP may be associated } \\
\text { with high risk [94] }\end{array}$ & $\begin{array}{l}\text { Positive } \\
\text { immunoreactivity } \\
\text { in amyloid plaques } \\
\text { and increased } \\
\text { concentration in } \\
\text { AD brain, } \\
\text { compared to } \\
\text { age-matched } \\
\text { subjects [95] }\end{array}$ & $\begin{array}{l}\text { Increased in } \\
\text { cerebral and } \\
\text { cerebellar cortex of } \\
\text { Huntington } \\
\text { patients [96] }\end{array}$ \\
\hline $\mathrm{TNF} \alpha$ & $\begin{array}{l}\text { Increased basal } \\
\text { levels in aged } \\
\text { laboratory animals } \\
\text { with week } \\
\text { induction injury } \\
\text { response [97] }\end{array}$ & $\begin{array}{l}\text { Modulates neuronal } \\
\text { cell loss in cerebral } \\
\text { ischemia [98] }\end{array}$ & $\begin{array}{l}\text { Increased } \\
\text { expression in AD } \\
\text { brain, along with } \\
\text { TNF-R1 [99] }\end{array}$ & $\begin{array}{l}\text { Increased in } \\
\text { plasma [100], CSF } \\
\text { of PD patients and } \\
\text { in PD brains, } \\
\text { especially in areas } \\
\text { with greatest loss } \\
\text { of dopaminergic } \\
\text { neurons [101] }\end{array}$ \\
\hline TGF $\beta 1$ & $\begin{array}{l}\text { Detected at low } \\
\text { levels in CSF and } \\
\text { produced in CNS } \\
\text { at low levels by } \\
\text { neuronal cells } \\
{[102]}\end{array}$ & $\begin{array}{l}\text { Increased in CNS and } \\
\text { CSF after stroke [103] }\end{array}$ & $\begin{array}{l}\text { Increased in areas } \\
\text { with amyloid } \\
\text { burden [104] }\end{array}$ & $\begin{array}{l}\text { CAA_-directly } \\
\text { related to amyloid } \\
\text { vascular deposition } \\
{[105]}\end{array}$ \\
\hline Adhesion molecules & $\begin{array}{l}\text { sVCAM increased } \\
{[106]}\end{array}$ & $\begin{array}{l}\text { sVCAM increased in } \\
\text { atherosclerotic disease } \\
{[107] ; \text { sE-selectin }} \\
\text { increased in severe } \\
\text { cerebrovascular disease } \\
{[108]}\end{array}$ & $\begin{array}{l}\text { sVCAM elevated in } \\
\text { late onset } \mathrm{AD}[50]\end{array}$ & $\begin{array}{l}\text { sVCAM increased } \\
\text { in Down } \\
\text { Syndrome }[100]\end{array}$ \\
\hline ROS & $\begin{array}{l}\text { Increased } \\
\text { accumulation with } \\
\text { aging [109] }\end{array}$ & $\begin{array}{l}\text { Increased in ischemia } \\
\text { animal models and } \\
\text { stroke patients [110] }\end{array}$ & $\begin{array}{l}\text { Increased: } \\
\mathrm{A} \beta \text {-related ROS } \\
\text { generation and } \\
\text { MAOS }[111]\end{array}$ & $\begin{array}{l}\text { Increased in PD in } \\
\text { vitro models [112] } \\
\text { and animal models } \\
{[113]}\end{array}$ \\
\hline Lipid metabolism & $\begin{array}{l}\text { Accumulation of } \\
\text { ceramides and free } \\
\text { cholesterol in } \\
\text { cerebral cortex } \\
{[114]}\end{array}$ & $\begin{array}{l}\text { Hypercholesterolemia } \\
\text { is a known risk factor } \\
\text { for } \mathrm{VaD}\end{array}$ & $\begin{array}{l}\text { Increased levels of } \\
\text { cholesterol, and } \\
\text { activation of } \\
\text { cholesterol } \\
\text { biosynthesis } \\
\text { pathway [115] }\end{array}$ & $\begin{array}{l}\text { PD dementia does } \\
\text { not correlate with } \\
\text { apoE } \\
\text { polymorphism or } \\
\text { lipid profile [116] }\end{array}$ \\
\hline
\end{tabular}


TABle 1: Continued.

\begin{tabular}{|c|c|c|c|c|}
\hline Parameter & Normal aging & Vascular dementia & Alzheimer's disease & $\begin{array}{l}\text { Other } \\
\text { neurodegenerative } \\
\text { disorders }\end{array}$ \\
\hline GLUT 1 & $\begin{array}{l}\text { Altered structure } \\
\text { and function of } \\
\text { GLUT-1 [117] }\end{array}$ & $\begin{array}{l}\text { Downregulated in } \\
\text { prolonged hypoxia } \\
{[118]}\end{array}$ & $\begin{array}{l}\text { Low expression in } \\
\text { AD hippocampus } \\
\text { and double } \\
\text { transgenic } \\
\text { APP/PS1 animal } \\
\text { model Learning } \\
\text { increases } \\
\text { expression in } \\
\text { mouse brain [119] }\end{array}$ & $\begin{array}{l}\text { Insufficiently } \\
\text { investigated in } \\
\text { neurodegenera- } \\
\text { tion, but involved } \\
\text { in "Glut-1 } \\
\text { deficiency } \\
\text { syndrome" - a } \\
\text { treatment-resistant } \\
\text { form of epilepsy } \\
\text { [120] }\end{array}$ \\
\hline BDNF & $\begin{array}{l}\text { Decreased mRNA } \\
\text { in human plasma } \\
\text { and hippocampus } \\
{[121]}\end{array}$ & $\begin{array}{l}\text { Increased expression } \\
\text { following hypoxic } \\
\text { stress in cell cultures } \\
{[122,123] \text { and lab }} \\
\text { animals }[123]\end{array}$ & $\begin{array}{l}\text { Decreased } \\
\text { expression in } \\
\text { hippocampus } \\
\text { temporal and } \\
\text { frontal cortex } \\
{[124]}\end{array}$ & $\begin{array}{l}\text { Reduced BDNF } \\
\text { expression in the } \\
\text { caudate and } \\
\text { putamen in HD } \\
\text { patients [52] } \\
\text { Reduced mRNA } \\
\text { BDNF expression } \\
{[125] \text { and protein }} \\
{[126] \text { in striatal }} \\
\text { neurons in PD } \\
\text { patients }\end{array}$ \\
\hline Calcium & $\begin{array}{l}\text { Reduced } \\
\text { homeostatic } \\
\text { reserve [33] }\end{array}$ & $\begin{array}{l}\text { Involved in } \\
\text { ischemia-induced } \\
\text { excitotoxicity [127] }\end{array}$ & $\begin{array}{l}\text { A } \beta \text { disrupts Ca } \\
\text { homeostasis in } \\
\text { cortical neuronal } \\
\text { cell cultures [117] }\end{array}$ & $\begin{array}{l}\text { Excitotoxicity and } \\
\text { excessive } \\
\mathrm{Ca}^{2+} \text {-mediated } \\
\text { nitric oxide } \\
\text { production are } \\
\text { believed to } \\
\text { contribute to the } \\
\text { death of } \\
\text { dopaminergic } \\
\text { neurons in PD } \\
\text { [118]; Huntingtin } \\
\text { transgenic mice } \\
\text { express } \\
\text { mitochondrial Ca } \\
\text { overload upon } \\
\text { glutamate } \\
\text { stimulation [119] }\end{array}$ \\
\hline
\end{tabular}

MAOS: membrane-associated oxidative stress VDCC: voltage dependent calcium channels, FTLD: frontotemporal lobar dementia, LBD: Lewy body dementia, and HD: Huntington disease.

\section{Acknowledgments}

This paper was supported by the Sectorial Operational Programme Human Resources Development (SOP HRD), financed from the European Social Fund and by the Romanian Government under contract number POSDRU/89/1.5/S/64109, and by the Executive Unit for Financing Higher Education, Research, Development and Innovation-Romania (UEFISCDI), Program 4 (Partnerships in Priority Domains), Grant no. 41-013/2007.

\section{References}

[1] F. Iemolo, G. Duro, C. Rizzo, L. Castiglia, V. Hachinski, and C. Caruso, "Pathophysiology of vascular dementia," Immunity \& Ageing, vol. 6, p. 13, 2009.
[2] J. M. Pearce, "Johann Jakob Wepfer (1620-95) and cerebral haemorrhage," Journal of Neurology, Neurosurgery and Psychiatry, vol. 62, no. 4, p. 387, 1997.

[3] H. Mast, T. K. Tatemichi, and J. P. Mohr, "Chronic brain ischemia: the contributions of Otto Binswanger and Alois Alzheimer to the mechanisms of vascular dementia," Journal of the Neurological Sciences, vol. 132, supplement 1, pp. 4-10, 1995.

[4] G. Román, "Vascular dementia: a historical background," International Psychogeriatrics, vol. 15, no. 1, pp. 11-13, 2003.

[5] V. C. Hachinski, L. D. Iliff, E. Zilhka et al., "Cerebral blood flow in dementia," Archives of Neurology, vol. 32, no. 9, pp. 632-637, 1975.

[6] V. C. Hachinski, "The decline and resurgence of vascular dementia," Canadian Medical Association Journal, vol. 142, no. 2, pp. 107-111, 1990. 
[7] S. Konno, J. Sterling Meyer, Y. Terayama, G. M. Margishvili, and K. F. Mortel, "Classification, diagnosis and treatment of vascular dementia," Drugs and Aging, vol. 11, no. 5, pp. 361373, 1997.

[8] A. Moretti, A. Gorini, and R. F. Villa, "Pharmacotherapy and prevention of vascular dementia," CNS \& Neurological Disorders_Drug Targets, vol. 10, no. 3, pp. 370-390, 2011.

[9] R. Stewart, "Vascular dementia: a diagnosis running out of time," British Journal of Psychiatry, vol. 180, pp. 152-156, 2002.

[10] R. Cacabelos, L. Fernandez-Novoa, J. M. Perez-Trullen, A. Franco-Maside, and X. A. Alvarez, "Serum histamine in Alzheimer's disease and multi-infarct dementia," Methods and Findings in Experimental and Clinical Pharmacology, vol. 14, no. 9, pp. 711-715, 1992.

[11] M. J. Schneck, "Vascular dementia," Topics in Stroke Rehabilitation, vol. 15, no. 1, pp. 22-26, 2008.

[12] C. Loeb and C. Gandolfo, "Diagnostic evaluation of degenerative and vascular dementia," Stroke, vol. 14, no. 3, pp. 399401, 1983.

[13] G. C. Roman, T. K. Tatemichi, T. Erkinjuntti et al., "Vascular dementia: diagnostic criteria for research studies: report of the NINDS-AIREN International Workshop," Neurology, vol. 43, no. 2, pp. 250-260, 1993.

[14] T. Pohjasvaara, R. Mantyla, R. Ylikoski, M. Kaste, and T. Erkinjuntti, "Comparison of different clinical criteria (DSM-III, ADDTC, ICD-10, NINDS-AIREN, DSM-IV) for the diagnosis of vascular dementia. National Institute of Neurological Disorders and Stroke," Stroke, vol. 31, no. 12, pp. 2952-2957, 2000.

[15] R. R. Sturrock, "A quantitative lifespan study of changes in cell number, cell division and cell death in various regions of the mouse forebrain," Neuropathology and Applied Neurobiology, vol. 5, no. 6, pp. 433-456, 1979.

[16] R. D. Terry, R. DeTeresa, and L. A. Hansen, "Neocortical cell counts in normal human adult aging," Annals of Neurology, vol. 21, no. 6, pp. 530-539, 1987.

[17] S. L. Vincent, A. Peters, and J. Tigges, "Effects of aging on the neurons within area 17 of rhesus monkey cerebral cortex," Anatomical Record, vol. 223, no. 3, pp. 329-341, 1989.

[18] D. A. Merrill, J. A. Roberts, and M. H. Tuszynski, "Conservation of neuron number and size in entorhinal cortex layers II, III, and V/VI of aged primates," Journal of Comparative Neurology, vol. 422, no. 3, pp. 396-401, 2000.

[19] A. Peters, D. Leahu, M. B. Moss, and K. J. McNally, "The effects of aging on area 46 of the frontal cortex of the rhesus monkey," Cerebral Cortex, vol. 4, no. 6, pp. 621-635, 1994.

[20] A. H. Gazzaley, M. M. Thakker, P. R. Hof, and J. H. Morrison, "Preserved number of entorhinal cortex layer II neurons in aged macaque monkeys," Neurobiology of Aging, vol. 18, no. 5, pp. 549-553, 1997.

[21] H. Soininen, M. Puranen, and P. J. Riekkinen, "Computed tomography findings in senile dementia and normal aging," Journal of Neurology Neurosurgery and Psychiatry, vol. 45, no. 1, pp. 50-54, 1982.

[22] R. I. Scahill, C. Frost, R. Jenkins, J. L. Whitwell, M. N. Rossor, and N. C. Fox, "A longitudinal study of brain volume changes in normal aging using serial registered magnetic resonance imaging," Archives of Neurology, vol. 60, no. 7, pp. 989-994, 2003.

[23] D. Mungas, D. Harvey, B. R. Reed et al., "Longitudinal volumetric MRI change and rate of cognitive decline," Neurology, vol. 65, no. 4, pp. 565-571, 2005.
[24] S. H. Freeman, R. Kandel, L. Cruz et al., "Preservation of neuronal number despite age-related cortical brain atrophy in elderly subjects without Alzheimer disease," Journal of Neuropathology and Experimental Neurology, vol. 67, no. 12, pp. 1205-1212, 2008.

[25] J. D. Grill and D. R. Riddle, "Age-related and laminar-specific dendritic changes in the medial frontal cortex of the rat," Brain Research, vol. 937, no. 1-2, pp. 8-21, 2002.

[26] J. M. de Brabander, R. J. Kramers, and H. B. Uylings, "Layer-specific dendritic regression of pyramidal cells with ageing in the human prefrontal cortex," European Journal of Neuroscience, vol. 10, no. 4, pp. 1261-1269, 1998.

[27] H. B. M. Uylings and J. M. De Brabander, "Neuronal changes in normal human aging and Alzheimer's disease," Brain and Cognition, vol. 49, no. 3, pp. 268-276, 2002.

[28] D. L. Dickstein, D. Kabaso, A. B. Rocher, J. I. Luebke, S. L. Wearne, and P. R. Hof, "Changes in the structural complexity of the aged brain," Aging Cell, vol. 6, no. 3, pp. 275-284, 2007.

[29] S. N. Burke and C. A. Barnes, "Neural plasticity in the ageing brain," Nature Reviews Neuroscience, vol. 7, no. 1, pp. 30-40, 2006.

[30] P. R. Rapp and M. Gallagher, "Preserved neuron number in the hippocampus of aged rats with spatial learning deficits," Proceedings of the National Academy of Sciences of the United States of America, vol. 93, no. 18, pp. 9926-9930, 1996.

[31] K. M. Kennedy and N. Raz, "Pattern of normal agerelated regional differences in white matter microstructure is modified by vascular risk," Brain Research, vol. 1297, pp. 41-56, 2009.

[32] J. H. Kramer, D. Mungas, B. R. Reed et al., "Longitudinal MRI and cognitive change in healthy elderly," Neuropsychology, vol. 21, no. 4, pp. 412-418, 2007.

[33] E. C. Toescu, "Normal brain ageing: models and mechanisms," Philosophical Transactions of the Royal Society B, vol. 360, no. 1464, pp. 2347-2354, 2005.

[34] B. N. Ames, M. K. Shigenaga, and T. M. Hagen, "Oxidants, antioxidants, and the degenerative diseases of aging," Proceedings of the National Academy of Sciences of the United States of America, vol. 90, no. 17, pp. 7915-7922, 1993.

[35] U. T. Brunk and A. Terman, "The mitochondrial-lysosomal axis theory of aging: accumulation of damaged mitochondria as a result of imperfect autophagocytosis," European Journal of Biochemistry, vol. 269, no. 8, pp. 1996-2002, 2002.

[36] E. C. Toescu and A. Verkhratsky, "Parameters of calcium homeostasis in normal neuronal ageing," Journal of Anatomy, vol. 197, no. 4, pp. 563-569, 2000.

[37] R. A. Cohen, "Hypertension and cerebral blood flow: implications for the development of vascular cognitive impairment in the elderly," Stroke, vol. 38, no. 6, pp. 17151717, 2007.

[38] H. Matsuda, T. Maeda, and M. Yamada, "Age-matched normal values and topographic maps for regional cerebral blood flow measurements by Xe-133 inhalation," Stroke, vol. 15, no. 2, pp. 336-342, 1984.

[39] C. Iadecola, L. Park, and C. Capone, "Threats to the mind: aging, amyloid, and hypertension," Stroke, vol. 40, no. 3, pp. S40-S44, 2009.

[40] A. S. Pirson, T. Vander Borght, and K. Van Laere, "Age and gender effects on normal regional cerebral blood flow," American Journal of Neuroradiology, vol. 27, no. 6, pp. 11611162, 2006.

[41] H. Zhou, G. M. Saidel, and J. C. Lamanna, "Cerebral blood flow adaptation to chronic hypoxia," Advances in 
Experimental Medicine and Biology, vol. 614, pp. 371-377, 2008.

[42] M. F. Ritz, F. Fluri, S. T. Engelter, N. Schaeren-Wiemers, and P. A. Lyrer, "Cortical and putamen age-related changes in the microvessel density and astrocyte deficiency in spontaneously hypertensive and stroke-prone spontaneously hypertensive rats," Current Neurovascular Research, vol. 6, no. 4, pp. 279-287, 2009.

[43] P. Angelopoulos, H. Agouridaki, H. Vaiopoulos et al., "Cytokines in Alzheimer's disease and vascular dementia," International Journal of Neuroscience, vol. 118, no. 12, pp. 1659-1672, 2008.

[44] I. L. Campbell, M. J. Hofer, and A. Pagenstecher, "Transgenic models for cytokine-induced neurological disease," Biochimica et Biophysica Acta, vol. 1802, no. 10, pp. 903-917, 2009.

[45] I. L. Campbell, A. K. Stalder, Y. Akwa, A. Pagenstecher, and V. C. Asensio, "Transgenic models to study the actions of cytokines in the central nervous system," NeuroImmunoModulation, vol. 5, no. 3-4, pp. 126-135, 1998.

[46] K. Akassoglou, J. Bauer, G. Kassiotis et al., "Oligodendrocyte apoptosis and primary demyelination induced by local TNF/p55TNF receptor signaling in the central nervous system of transgenic mice: models for multiple sclerosis with primary oligodendrogliopathy," American Journal of Pathology, vol. 153, no. 3, pp. 801-813, 1998.

[47] L. Batti and J. J. O'Connor, “Tumor necrosis factor- $\alpha$ impairs the recovery of synaptic transmission from hypoxia in rat hippocampal slices," Journal of Neuroimmunology, vol. 218, no. 1-2, pp. 21-27, 2010.

[48] I. Ginis, J. M. Hallenbeck, J. Liu, M. Spatz, R. Jaiswal, and E. Shohami, "Tumor necrosis factor and reactive oxygen species cooperative cytotoxicity is mediated via inhibition of NFkappaB," Molecular Medicine, vol. 6, no. 12, pp. 1028-1041, 2000.

[49] D. Farfara, V. Lifshitz, and D. Frenkel, "Neuroprotective and neurotoxic properties of glial cells in the pathogenesis of Alzheimer's disease: Alzheimer's Review Series," Journal of Cellular and Molecular Medicine, vol. 12, no. 3, pp. 762-780, 2008.

[50] G. Zuliani, M. Cavalieri, M. Galvani et al., "Markers of endothelial dysfunction in older subjects with late onset Alzheimer's disease or vascular dementia," Journal of the Neurological Sciences, vol. 272, no. 1-2, pp. 164-170, 2008.

[51] R. L. Zhang, M. Chopp, Z. G. Zhang et al., "E-selectin in focal cerebral ischemia and reperfusion in the rat," Journal of Cerebral Blood Flow and Metabolism, vol. 16, no. 6, pp. 11261136, 1996.

[52] H. Wakita, C. Ruetzler, K. O. Illoh et al., "Mucosal tolerization to E-selectin protects against memory dysfunction and white matter damage in a vascular cognitive impairment model," Journal of Cerebral Blood Flow and Metabolism, vol. 28, no. 2, pp. 341-353, 2008.

[53] D. Hu, F. Serrano, T. D. Oury, and E. Klann, "Agingdependent alterations in synaptic plasticity and memory in mice that overexpress extracellular superoxide dismutase," Journal of Neuroscience, vol. 26, no. 15, pp. 3933-3941, 2006.

[54] A. Popa-Wagner, A. M. Buga, and Z. Kokaia, "Perturbed cellular response to brain injury during aging," Ageing Research Reviews, vol. 10, no. 1, pp. 71-79, 2011.

[55] A. Canuelo, E. Siles, R. Martinez-Romero, M. A. Peinado, and E. Martinez-Lara, "The nitric oxide system response to hypoxia/reoxygenation in the aged cerebral cortex," Experimental Gerontology, vol. 42, no. 12, pp. 1137-1145, 2007.
[56] P. Mander and G. C. Brown, "Nitric oxide, hypoxia and brain inflammation," Biochemical Society Transactions, vol. 32, no. 6, pp. 1068-1069, 2004.

[57] A. Scorziello, C. Pellegrini, A. Secondo et al., "Neuronal NOS activation during oxygen and glucose deprivation triggers cerebellar granule cell death in the later reoxygenation phase," Journal of Neuroscience Research, vol. 76, no. 6, pp. 812-821, 2004.

[58] R. M. Adibhatla and J. F. Hatcher, "Altered lipid metabolism in brain injury and disorders," Subcellular Biochemistry, vol. 49, pp. 241-268, 2008.

[59] L. Tapia-Arancibia, E. Aliaga, M. Silhol, and S. Arancibia, "New insights into brain BDNF function in normal aging and Alzheimer disease," Brain Research Reviews, vol. 59, no. 1, pp. 201-220, 2008.

[60] K. M. Kennedy, K. M. Rodrigue, S. J. Land, and N. Raz, "BDNF Val66Met polymorphism influences age differences in microstructure of the Corpus Callosum," Frontiers in Human Neuroscience, vol. 3, p. 19, 2009.

[61] S. K. Hota, K. Barhwal, S. B. Singh, and G. Ilavazhagan, "Chronic hypobaric hypoxia induced apoptosis in CA1 region of hippocampus: a possible role of NMDAR mediated p75NTR upregulation," Experimental Neurology, vol. 212, no. 1, pp. 5-13, 2008.

[62] K. M. Langa, N. L. Foster, and E. B. Larson, "Mixed dementia: emerging concepts and therapeutic implications," Journal of the American Medical Association, vol. 292, no. 23, pp. 29012908, 2004.

[63] A. D. Korczyn, "Mixed dementia-the most common cause of dementia," Annals of the New York Academy of Sciences, vol. 977, pp. 129-134, 2002.

[64] K. A. Jellinger and J. Attems, "Neuropathological evaluation of mixed dementia," Journal of the Neurological Sciences, vol. 257, no. 1-2, pp. 80-87, 2007.

[65] K. A. Jellinger and J. Attems, "Is there pure vascular dementia in old age?" Journal of the Neurological Sciences, vol. 299, no. 1-2, pp. 150-154, 2010.

[66] A. B. Scheibel, T. Duong, and R. Jacobs, "Alzheimer's disease as a capillary dementia," Annals of Medicine, vol. 21, no. 2, pp. 103-107, 1989.

[67] J. C. De La Torre, "Is Alzheimer's disease a neurodegenerative or a vascular disorder? Data, dogma, and dialectics," Lancet Neurology, vol. 3, no. 3, pp. 184-190, 2004.

[68] R. Pluta and M. Ułamek, "Brain ischemia and ischemic blood-brain barier as etiological factors in sporadic Alzheimer's disease," Neuropsychiatric Disease and Treatment, vol. 4, no. 5, pp. 855-864, 2008.

[69] X. Zhang, K. Zhou, R. Wang et al., "Hypoxia-inducible factor $1 \alpha($ HIF- $1 \alpha)$-mediated hypoxia increases BACE1 expression and $\beta$-amyloid generation," Journal of Biological Chemistry, vol. 282, no. 15, pp. 10873-10880, 2007.

[70] C. Kieda, R. Greferath, C. C. Da Silva, K. C. Fylaktakidou, J. M. Lehn, and C. Nicolau, "Suppression of hypoxia-induced HIF- $1 \alpha$ and of angiogenesis in endothelial cells by myoinositol trispyrophosphate-treated erythrocytes," Proceedings of the National Academy of Sciences of the United States of America, vol. 103, no. 42, pp. 15576-15581, 2006.

[71] A. Biolo, R. Greferath, D. A. Siwik et al., "Enhanced exercise capacity in mice with severe heart failure treated with an allosteric effector of hemoglobin, myo-inositol trispyrophosphate," Proceedings of the National Academy of Sciences of the United States of America, vol. 106, no. 6, pp. 1926-1929, 2009. 
[72] W. J. Lukiw, Y. Zhao, and G. C. Jian, "An NF- $\kappa$ Bsensitive micro RNA-146a-mediated inflammatory circuit in alzheimer disease and in stressed human brain cells," Journal of Biological Chemistry, vol. 283, no. 46, pp. 31315-31322, 2008.

[73] R. von Bernhardi, G. Ramirez, R. Toro, and J. Eugenin, "Pro-inflammatory conditions promote neuronal damage mediated by Amyloid Precursor Protein and decrease its phagocytosis and degradation by microglial cells in culture," Neurobiology of Disease, vol. 26, no. 1, pp. 153-164, 2007.

[74] G. M. Cole, T. Morihara, G. P. Lim, F. Yang, A. Begum, and S. A. Frautschy, "NSAID and antioxidant prevention of Alzheimer's disease: lessons from in vitro and animal models," Annals of the New York Academy of Sciences, vol. 1035, pp. 68-84, 2004.

[75] L. Munoz, H. Ranaivo, S. M. Roy et al., "A novel p38 $\alpha$ MAPK inhibitor suppresses brain proinflammatory cytokine upregulation and attenuates synaptic dysfunction and behavioral deficits in an Alzheimer's disease mouse model," Journal of Neuroinflammation, vol. 4, article no. 21, 2007.

[76] L. F. Lue, L. Brachova, W. H. Civin, and J. Rogers, "Inflammation, $\mathrm{A} \beta$ deposition, and neurofibrillary tangle formation as correlates of Alzheimer's disease neurodegeneration," Journal of Neuropathology and Experimental Neurology, vol. 55, no. 10, pp. 1083-1088, 1996.

[77] A. S. Lanzrein, C. M. Johnston, V. H. Perry, K. A. Jobst, E. M. King, and A. D. Smith, "Longitudinal study of inflammatory factors in serum, cerebrospinal fluid, and brain tissue in Alzheimer disease: interleukin- $\beta$, interleukin-6, interleukin-1 receptor antagonist, tumor necrosis factor$\alpha$, the soluble tumor necrosis factor receptors I and II, and $\alpha 1$-antichymotrypsin," Alzheimer Disease and Associated Disorders, vol. 12, no. 3, pp. 215-227, 1998.

[78] C. E. Shepherd, E. Thiel, H. McCann, A. J. Harding, and G. M. Halliday, "Cortical inflammation in Alzheimer disease but not dementia with Lewy bodies," Archives of Neurology, vol. 57, no. 6, pp. 817-822, 2000.

[79] R. G. Cutler, J. Kelly, K. Storie et al., "Involvement of oxidative stress-induced abnormalities in ceramide and cholesterol metabolism in brain aging and Alzheimer's disease," Proceedings of the National Academy of Sciences of the United States of America, vol. 101, no. 7, pp. 2070-2075, 2004.

[80] Y. Christen, "Oxidative stress and Alzheimer disease," American Journal of Clinical Nutrition, vol. 71, no. 2, 2000.

[81] G. Tibolla, G. D. Norata, C. Meda et al., "Increased atherosclerosis and vascular inflammation in APP transgenic mice with apolipoprotein E deficiency," Atherosclerosis, vol. 210, no. 1, pp. 78-87, 2010.

[82] G. Santpere, B. Puig, and I. Ferrer, "Oxidative damage of 14-3-3 zeta and gamma isoforms in Alzheimer's disease and cerebral amyloid angiopathy," Neuroscience, vol. 146, no. 4, pp. 1640-1651, 2007.

[83] G. L. Bowman and J. F. Quinn, "Alzheimer's disease and the blood-brain barrier: past, present and future," Aging Health, vol. 4, no. 1, pp. 47-57, 2008.

[84] B. J. Carey, P. J. Eames, M. J. Blake, R. B. Panerai, and J. F. Potter, "Dynamic cerebral autoregulation is unaffected by aging," Stroke, vol. 31, no. 12, pp. 2895-2900, 2000.

[85] Y. S. Shim, D. W. Yang, B. S. Kim, Y. M. Shon, and Y. A. Chung, "Comparison of regional cerebral blood flow in two subsets of subcortical ischemic vascular dementia: statistical parametric mapping analysis of SPECT," Journal of the Neurological Sciences, vol. 250, no. 1-2, pp. 85-91, 2006.
[86] N. Schuff, S. Matsumoto, J. Kmiecik et al., "Cerebral blood flow in ischemic vascular dementia and Alzheimer's disease, measured by arterial spin-labeling magnetic resonance imaging," Alzheimer's and Dementia, vol. 5, no. 6, pp. 454-462, 2009.

[87] S. E. Palhagen, S. Ekberg, J. Walinder, A. K. Granerus, and G. Granerus, "HMPAO SPECT in Parkinson's disease (PD) with major depression (MD) before and after antidepressant treatment," Journal of Neurology, vol. 256, no. 9, pp. 15101518, 2009.

[88] S. Shimizu, H. Hanyu, K. Hirao, T. Sato, T. Iwamoto, and K. Koizumi, "Value of analyzing deep gray matter and occipital lobe perfusion to differentiate dementia with Lewy bodies from Alzheimer's disease," Annals of Nuclear Medicine, vol. 22, no. 10, pp. 911-916, 2008.

[89] T. Matsuda, T. Abe, J. L. Wu, M. Fujiki, and H. Kobayashi, "Hypoxia-inducible factor- $1 \alpha$ DNA induced angiogenesis in a rat cerebral ischemia model," Neurological Research, vol. 27, no. 5, pp. 503-508, 2005.

[90] N. S. Patel, V. S. Mathura, C. Bachmeier et al., "Alzheimer's beta-amyloid peptide blocks vascular endothelial growth factor mediated signaling via direct interaction with VEGFR2," Journal of Neurochemistry, vol. 112, no. 1, pp. 66-76, 2009.

[91] S. B. Solerte, E. Ferrari, G. Cuzzoni et al., "Decreased release of the angiogenic peptide vascular endothelial growth factor in alzheimer's disease: recovering effect with insulin and DHEA sulfate," Dementia and Geriatric Cognitive Disorders, vol. 19, no. 1, pp. 1-10, 2005.

[92] B. Borroni, S. Ghezzi, C. Agosti et al., "Preliminary evidence that VEGF genetic variability confers susceptibility to frontotemporal lobar degeneration," Rejuvenation Research, vol. 11, no. 4, pp. 773-780, 2008.

[93] I. L. Campbell, "Structural and functional impact of the transgenic expression of cytokines in the CNS," Annals of the New York Academy of Sciences, vol. 840, pp. 83-96, 1998.

[94] G. Ravaglia, P. Forti, F. Maioli et al., "Blood inflammatory markers and risk of dementia: the Conselice Study of Brain Aging," Neurobiology of Aging, vol. 28, no. 12, pp. 1810-1820, 2007.

[95] M. Hüll, S. Strauss, M. Berger, B. Volk, and J. Bauer, "The participation of interleukin-6, a stress-inducible cytokine, in the pathogenesis of Alzheimer's disease," Behavioural Brain Research, vol. 78, no. 1, pp. 37-41, 1996.

[96] A. Silvestroni, R. L. M. Faull, A. D. Strand, and T. Möllera, "Distinct neuroinflammatory profile in post-mortem human Huntington's disease," NeuroReport, vol. 20, no. 12, pp. 10981103, 2009.

[97] O. Campuzano, M. M. Castillo-Ruiz, L. Acarin, B. Castellano, and B. Gonzalez, "Increased levels of proinflammatory cytokines in the aged rat brain attenuate injury-induced cytokine response after excitotoxic damage," Journal of Neuroscience Research, vol. 87, no. 11, pp. 2484-2497, 2009.

[98] L. C. Pettigrew, M. S. Kindy, S. Scheff et al., "Focal cerebral ischemia in the TNFalpha-transgenic rat," Journal of Neuroinflammation, vol. 5, article no. 47, 2008.

[99] M. Zhao, D. H. Cribbs, A. J. Anderson et al., "The induction of the TNF $\alpha$ death domain signaling pathway in Alzheimer's disease brain," Neurochemical Research, vol. 28, no. 2, pp. 307-318, 2003.

[100] F. Licastro, M. Chiappelli, M. Ruscica, V. Carnelli, and M. M. Corsi, "Altered cytokine and acute phase response protein levels in the blood of children with Downs syndrome, relationship with dementia of Alzheimer's type," International 
Journal of Immunopathology and Pharmacology, vol. 18, no. 1, pp. 165-172, 2005.

[101] M. Mogi, M. Harada, P. Riederer, H. Narabayashi, K. Fujita, and T. Nagatsu, "Tumor necrosis factor- $\alpha$ (TNF- $\alpha$ ) increases both in the brain and in the cerebrospinal fluid from parkinsonian patients," Neuroscience Letters, vol. 165, no. 1-2, pp. 208-210, 1994.

[102] T. C. Brionne, I. Tesseur, E. Masliah, and T. Wyss-Coray, "Loss of TGF- $\beta 1$ leads to increased neuronal cell death and microgliosis in mouse brain," Neuron, vol. 40, no. 6, pp. 1133-1145, 2003.

[103] J. Krupinski, P. Kumar, S. Kumar, and J. Kaluza, "Increased expression of TGF- $\beta 1$ in brain tissue after ischemic stroke in humans," Stroke, vol. 27, no. 5, pp. 852-857, 1996.

[104] I. Blasko, M. Stampfer-Kountchev, P. Robatscher, R. Veerhuis, P. Eikelenboom, and B. Grubeck-Loebenstein, "How chronic inflammation can affect the brain and support the development of Alzheimer's disease in old age: the role of microglia and astrocytes," Aging Cell, vol. 3, no. 4, pp. 169-176, 2004.

[105] T. Wyss-Coray, E. Masliah, M. Mallory et al., "Amyloidogenic role of cytokine TGF- $\beta 1$ in transgenic mice and in Alzheimer's disease," Nature, vol. 389, no. 6651, pp. 603-606, 1997.

[106] M. Ewers, M. M. Mielke, and H. Hampel, "Blood-based biomarkers of microvascular pathology in Alzheimer's disease," Experimental Gerontology, vol. 45, no. 1, pp. 75-79, 2009.

[107] K. Peter, P. Nawroth, C. Conradt et al., "Circulating vascular cell adhesion molecule-1 correlates with the extent of human atherosclerosis in contrast to circulating intercellular adhesion molecule-1, E-selectin, P-selectin, and thrombomodulin," Arteriosclerosis, Thrombosis, and Vascular Biology, vol. 17, no. 3, pp. 505-512, 1997.

[108] K. Fassbender, T. Bertsch, O. Mielke, F. Mühlhauser; and M. Hennerici, "Adhesion molecules in cerebrovascular diseases: evidence for an inflammatory endothelial activation in cerebral large- and small-vessel disease," Stroke, vol. 30, no. 8, pp. 1647-1650, 1999.

[109] C. D. Smith, J. M. Carney, P. E. Starke-Reed et al., "Excess brain protein oxidation and enzyme dysfunction in normal aging and in Alzheimer disease," Proceedings of the National Academy of Sciences of the United States of America, vol. 88, no. 23, pp. 10540-10543, 1991.

[110] K. Choi, J. Kim, G. W. Kim, and C. Chulhee, "Oxidative stress-induced necrotic cell death via mitochondiradependent burst of reactive oxygen species," Current Neurovascular Research, vol. 6, no. 4, pp. 213-222, 2009.

[111] Q. Shi and G. E. Gibson, "Oxidative stress and transcriptional regulation in Alzheimer disease," Alzheimer Disease and Associated Disorders, vol. 21, no. 4, pp. 276-291, 2007.

[112] A. R. Esteves, D. M. Arduino, R. H. Swerdlow, C. R. Oliveira, and S. M. Cardoso, "Oxidative stress involvement in alphasynuclein oligomerization in Parkinson's disease cybrids," Antioxidants and Redox Signaling, vol. 11, no. 3, pp. 439-448, 2009.

[113] R. L. Miller, M. James-Kracke, G. Y. Sun, and A. Y. Sun, "Oxidative and inflammatory pathways in Parkinson's disease," Neurochemical Research, vol. 34, no. 1, pp. 55-65, 2009.

[114] S. Yehuda, S. Rabinovitz, R. L. Carasso, and D. I. Mostofsky, "The role of polyunsaturated fatty acids in restoring the aging neuronal membrane," Neurobiology of Aging, vol. 23, no. 5, pp. 843-853, 2002.
[115] M. Recuero, M. C. Vicente, A. Martínez-García et al., "A free radical-generating system induces the cholesterol biosynthesis pathway: a role in Alzheimer's disease," Aging Cell, vol. 8, no. 2, pp. 128-139, 2009.

[116] B. Jasinska-Myga, G. Opala, C. G. Goetz et al., "Apolipoprotein E gene polymorphism, total plasma cholesterol level, and Parkinson disease dementia," Archives of Neurology, vol. 64, no. 2, pp. 261-265, 2007.

[117] E. Ferreiro, R. Resende, R. Costa, C. R. Oliveira, and C. M. F. Pereira, "An endoplasmic-reticulum-specific apoptotic pathway is involved in prion and amyloid-beta peptides neurotoxicity," Neurobiology of Disease, vol. 23, no. 3, pp. 669-678, 2006.

[118] M. F. Beal, "Excitotoxicity and nitric oxide in Parkinson's disease pathogenesis," Annals of Neurology, vol. 44, no. 3 supplement 1, pp. S110-S114, 1998.

[119] T. S. Tang, E. Slow, V. Lupu et al., "Disturbed Ca2+ signalling and apoptosis of medium spiny neurons in Huntington's disease," Proceedings of the National Academy of Sciences of the United States of America, vol. 102, no. 7, pp. 2602-2607, 2005.

[120] M. Raza, L. S. Deshpande, R. E. Blair, D. S. Carter, S. Sombati, and R. J. DeLorenzo, "Aging is associated with elevated intracellular calcium levels and altered calcium homeostatic mechanisms in hippocampal neurons," Neuroscience Letters, vol. 418, no. 1, pp. 77-81, 2007.

[121] M. J. Webster, M. M. Herman, J. E. Kleinman, and C. Shannon Weickert, "BDNF and trkB mRNA expression in the hippocampus and temporal cortex during the human lifespan," Gene Expression Patterns, vol. 6, no. 8, pp. 941-951, 2006.

[122] A. M. Marini, J. Choi, and R. Labutta, "Synaptic deprivation and age-related vulnerability to hypoxic-ischemic neuronal injury: a hypothesis," Annals of the New York Academy of Sciences, vol. 939, pp. 238-253, 2001.

[123] M. Walton, B. Connor, P. Lawlor et al., "Neuronal death and survival in two models of hypoxic-ischemic brain damage," Brain Research Reviews, vol. 29, no. 2-3, pp. 137-168, 1999.

[124] H. S. Phillips, J. M. Hains, M. Armanini, G. R. Laramee, S. A. Johnson, and J. W. Winslow, "BDNF mRNA is decreased in the hippocampus of individuals with Alzheimer's disease," Neuron, vol. 7, no. 5, pp. 695-702, 1991.

[125] D. W. Howells, M. J. Porritt, J. Y. F. Wong et al., "Reduced BDNF mRNA expression in the Parkinson's disease substantia nigra," Experimental Neurology, vol. 166, no. 1, pp. 127$135,2000$.

[126] K. Parain, M. G. Murer, Q. Yan et al., "Reduced expression of brain-derived neurotrophic factor protein in Parkinson's disease substantia nigra," NeuroReport, vol. 10, no. 3, pp. 557561, 1999.

[127] R. Bull, J. P. Finkelstein, J. Galvez et al., "Ischemia enhances activation by $\mathrm{Ca} 2+$ and redox modification of ryanodine receptor channels from rat brain cortex," The Journal of Neuroscience, vol. 28, no. 38, pp. 9463-9472, 2008. 


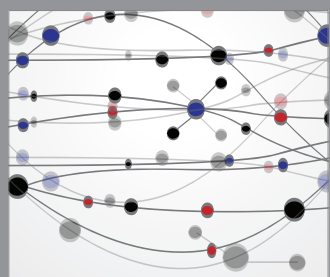

The Scientific World Journal
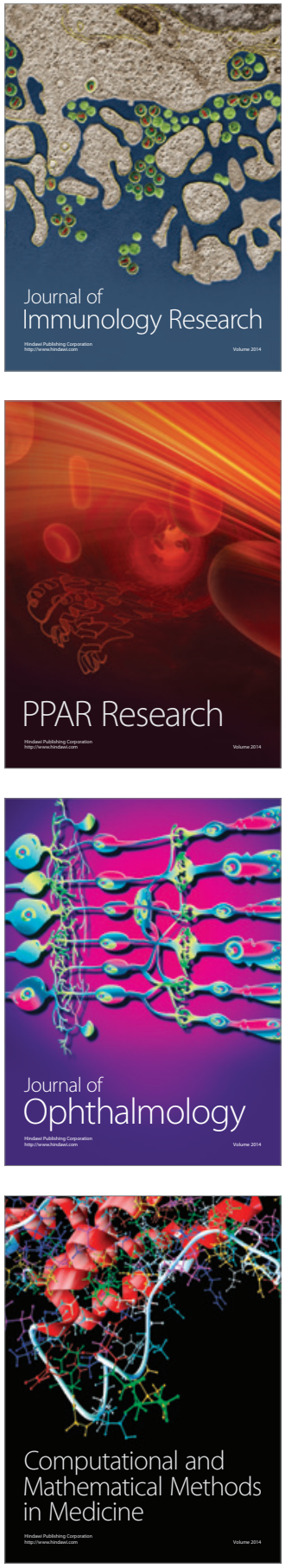

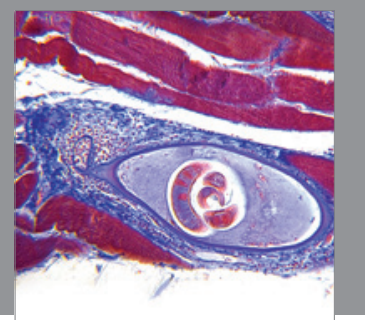

Gastroenterology

Research and Practice
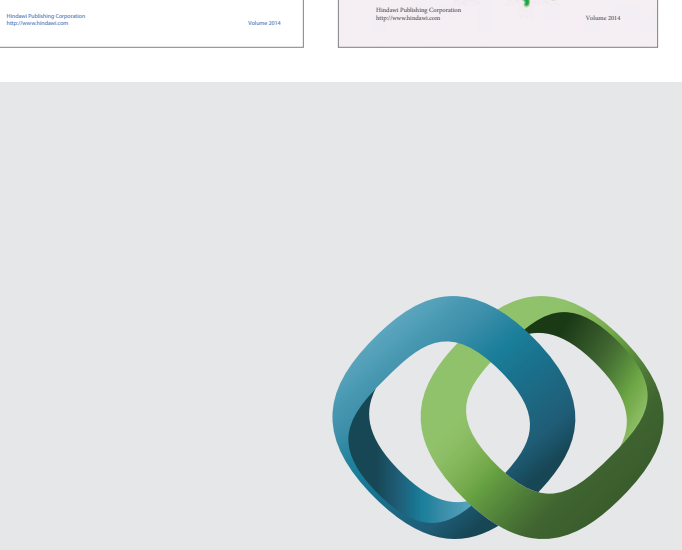

\section{Hindawi}

Submit your manuscripts at

http://www.hindawi.com
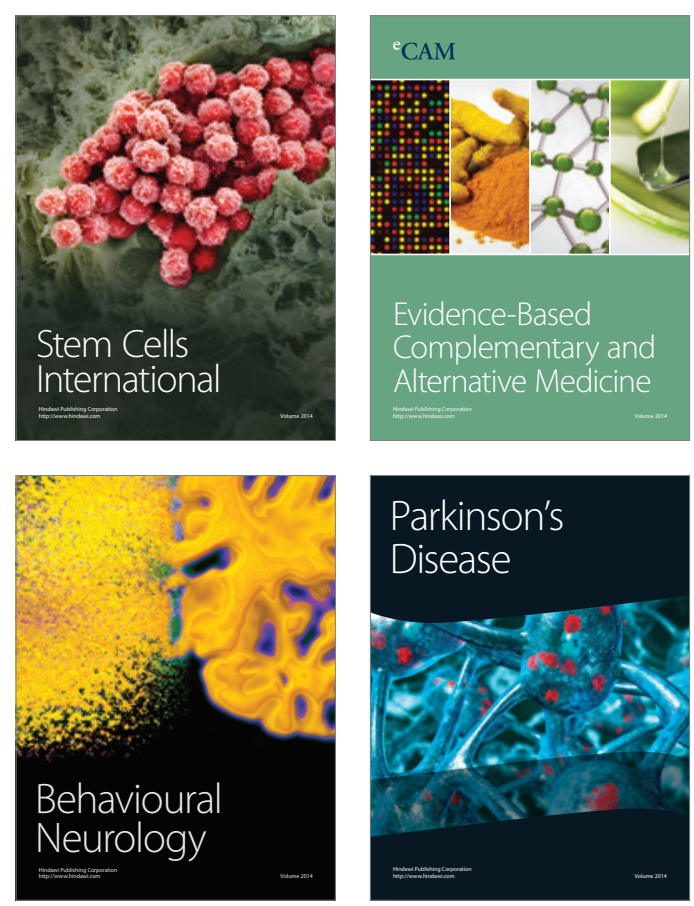

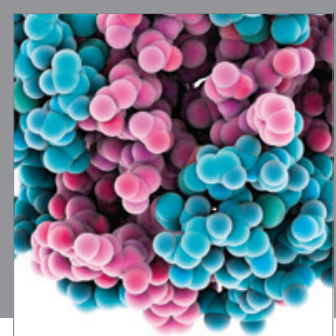

Journal of
Diabetes Research

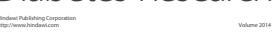

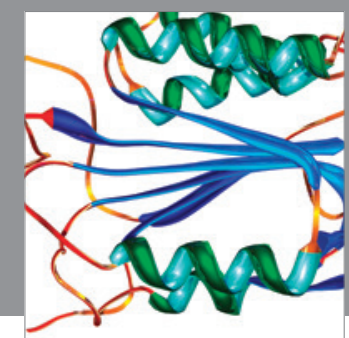

Disease Markers
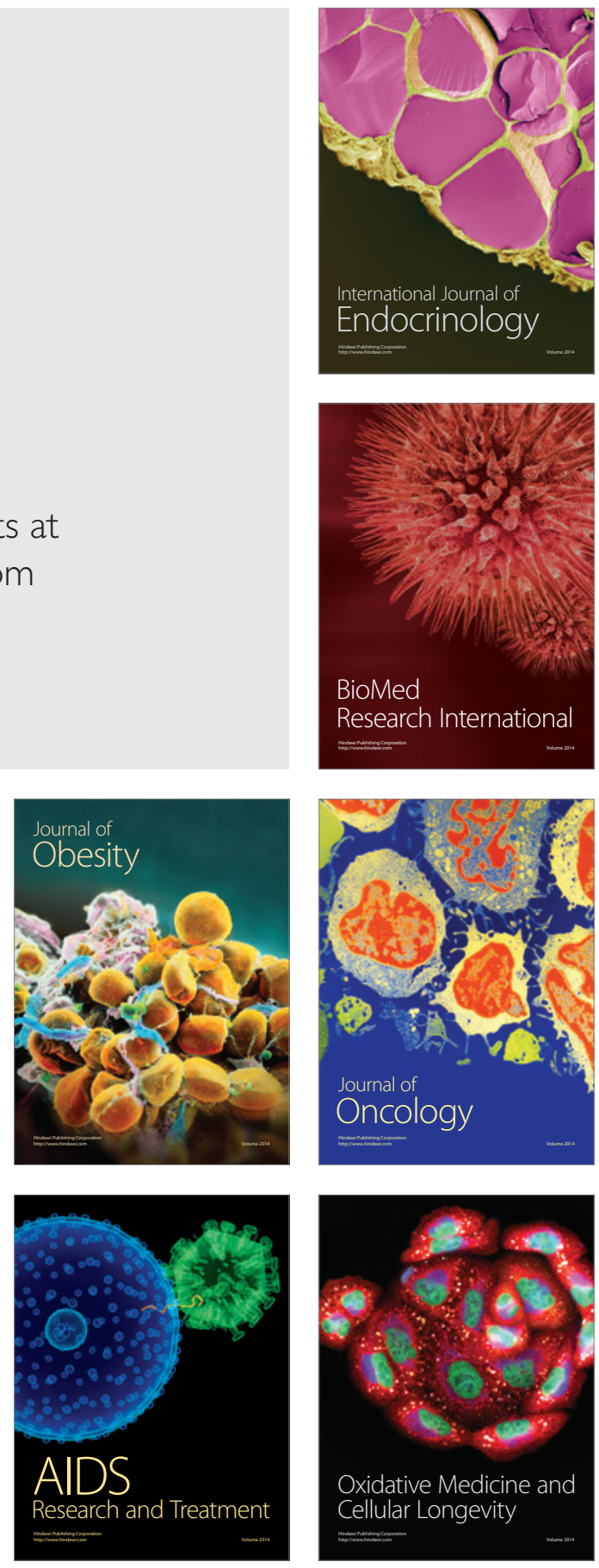